\title{
PENGARUH BUDAYA ASING TERHADAP PERKEMBANGAN BATIK PEKALONGAN
}

\author{
Suyani *)
}

\begin{abstract}
ABSTRACK
Batik is a craft that has high artistic value and has become part of Indonesian culture since long. Pekalongan is a city located in the northern coast of the island of Java or in other words, a city located on the North Coast of Java. Pekalongan area has a sea port enlivening trade traffic between islands in the archipelago. The existence of the port affects the socioeconomic and demographic developments. The attitude of openness that supported high creativity can make batik Pekalongan withstand any difficult time, able to create new creations. Based on this background to discuss the growth and development of Pekalongan batik using the theory of acculturation or culture contect that a particular culture is confronted with the elements of a foreign culture in such a way that the elements of a foreign culture was gradually accepted and processed into in their own culture without losing their own cultural identity. In this case it is clear that batik is the art of Indonesian culture which is admired by foreign countries. In its development as a cultural work, valuable work can not be separated from the influence of age and environment. Facts in the course of history prove that the two elements have proven this effect and spur trigger that is consistent with the presence of batik culture affecting tone.
\end{abstract}

Keywords: Pekalongan, Batik, culture, growth

\begin{abstract}
ABSTRAK
Batik adalah kerajinan yang memiliki nilai seni tinggi dan telah menjadi bagian budaya Indonesia sejak lama. Pekalongan merupakan salah satu kota yang terletak di pantai Utara pulau Jawa atau dengan kata lain kota yang berada di Pesisir Utara Jawa. Daerah Pekalongan memiliki pelabuhan laut yang ikut meramaikan lalu lintas perdagangan antar pulau di Nusantara. Adanya pelabuhan itu mempengaruhi perkembangan sosial ekonomi maupun kependudukan. Sikap keterbukaan yang didukung kreatifitas tinggi menjadikan pembatik Pekalongan sanggup bertahan di masa sesulit apapun, sanggup menciptakan kreasi-kreasi baru. Berdasarkan latar belakang tersebut untuk membahas lebih dalam tumbuh dan berkembangnya batik Pekalongan menggunakan teori akulturasi atau culture contect bahwa suatu kebudayaan tertentu yang dihadapkan dengan unsur-unsur dari suatu kebudayaan asing dengan sedemikian rupa, sehingga unsur-unsur kebudayaan asing itu lambat laun diterima dan diolah ke dalam kebudayaan sendiri tanpa menyebabkan hilangnya kepribadian budaya itu sendiri. Dalam hal ini jelas batik merupakan karya seni budaya bangsa Indonesia yang dikagumi
\end{abstract}

* Suyani, Mahasiswa Pascasarjana Institut Seni Indonesia Yogyakarta 
oleh mancanegara. Dalam perkembangannya sebagai suatu karya budaya, karya adiluhung yang tidak bisa terlepas dari pengaruh jaman dan lingkungan. Fakta dalam perjalan sejarah membuktikan telah membuktikan bahwa kedua unsur pengaruh ini memicu dan memacu kehadiran batik yang selaras dengan nada budaya yang mempengaruhinya.

Kata Kunci : Pekalongan, Batik, budaya, perkembangan

\section{PENDAHULUAN}

Batik adalah kerajinan yang memiliki nilai seni tinggi dan telah menjadi bagian budaya Indonesia sejak lama.Pekalongan merupakan salah satu kota yang terletak di pantai Utara pulau Jawa atau dengan kata lain kota yang berada di Pesisir Utara Jawa. Sejak masa Hindu-Islam sampai kemerdekaan, Pekalongan menempati posisi yang jauh dari pusat kekuasaaan. Secara otonomi, Pekalongan tumbuh sebagai kota niaga dan sejak awal kota tersebut sudah menjadi daerah perdagangan sampai dengan masa kolonial. Daerah Pekalongan memiliki pelabuhan laut yang ikut meramaikan lalu lintas perdagangan antar pulau di Nusantara. Adanya pelabuhan itu mempengaruhi perkembangan sosial ekonomi maupun kependudukan. Urbanisasi kaum migran, baik dari daerah maupun dari luar ikut menentukan perkembangan kota Pekalongan (Kusnin Asa,2006:18). Pekalongan yang merupakan salah satu kota penghasil batik yang cukup terkenal di Indonesia. Eksistensinya tidak hanya dikenal oleh masyarakat Jawa akan tetapi mampu mempengaruhi daerah disekitarnya seperti Trusni, Cirebon, bahkan batik Pekalongan pun mampu menarik produsen mancanegara. Batik Pekalongan dahulu dibuat tidak jauh berbeda dengan batik Keraton (Yogyakarta, Solo). Adanya pengaruh dari para pendatang menjadikan batik Pekalongan akhirnya berbeda dengan batik Keraton.
Masyarakat pembatik di Pekalongan terkenal sangat kreatif dan dengan mudah menerima paham dan pemikiran baru (Dudung Alie Syahbana : 101).

Perjalanan panjang yang akhirnya menentukan batik Pekalongan tampil beda dari daerah lain. Meskipun demikian keanekaragaman dan kepercayaan asli masyarakat Pekalongan juga turut menentukan. Sikap keterbukaan yang didukung kreatifitas tinggi menjadikan pembatik Pekalongan sanggup bertahan di masa-masa sesulit apapun, sanggup menciptakan kreasi-kreasi baru. Pengaruh budaya seperti India, Cina, Belanda, Arab sangat mempengaruhi perkembangan batik, khususnya dalam hal ini yang berada di Pekalongan. Batik Pekalongan khususnya, merupakan cerminan kekayaan aneka bangsa. Artinya masyarakat pendukung mempengaruhi budaya yang ada dan budaya yang ada dipengaruhi juga oleh masyarakat pendukungnya juga.

\section{PEMBAHASAN}

Pada hakekatnya kebudayaan merupakan hasil "budi" dan "daya" berupa cipta, karsa dan rasa manusia yaitu mengangkat derajat manusia sebagai makhluk Tuhan yang paling tinggi diantara makhluk Tuhan yang lain. Dalam bahasa Indonesia kebudayaan sendiri berasal dari bahasa Sanskerta budddayah bentuk jamak dari kata budhi (budi atau akal). Dengan adanya budaya kita bisa mengetahui 
tingkat keberadapan, pendidikan, status sosial manusia pendukungnya. Ruang lingkup konsepsi kebudayaan sangat bervariasi dan setiap pembatasan arti yang diberikan akan sangat dipengaruhi oleh dasar pemikiran tentang asas-asas pembentukan masyarakat dan kebudayaan. Koentjaraningrat (1984: 180-181) sendiri mendefinikan kebudayaan merupakan :

“ keseluruhan sistem gagasan, tindakan dan hasil karya manusia dalam rangka kehidupan masyarakat yang dijadikan milik diri manusia dengan belajar".

Kebudayaan dalam kehidupan sehari-hari adalah seluruhan cara kehidupan dari masyarakat manapun dan tidak hanya mengenai sebagian dari cara hidup itu, yaitu bagian yang oleh masyarakat dianggap lebih tinggi atau lebih diinginkan. Tiap masyarakat mempunyai budaya, akan tetapi dari masing-masing masyarakat tersebut tingkatanya berbedabeda (Raplh, 1999: 30). Manusia dan kebudayaan tidak dapat dipisahkan. Sementara pendukung kebudayaan adalah manusia itu sendiri. Sekalipun manusia mati tapi kebudayaan akan diwariskan kepada keturunannya. Pewarisan kebudayaan manusia tidak selalu terjadi secara vertikal atau kepada anak cucu mereka, malainkan dapat pula secara horisontal yaitu manusia yang satu dengan manusia lain. Berbagai pengalaman manusia tentang kebuudayaan diteruskan dan dikomunikasikan kepada generasi berikutnya oleh individu lain karena ia mampu mengembangkan gagasan itu dalam lambang vokal berupa bahasa isan atau tertulis. Hal ini sejalan dengan apa yang disebut dengan holisme.
Dimana sifat-sifat individu sematamata masih merupakan suatu fungsi tempat mereka dalam masyarakat atau sistem makna yang lebih luas, secara lebih khusus, konsep ini mengharuskan bahwa identitas orang ditentukan oleh keanggotaan kelompok mereka karena identitas dihasilkan oleh berbagai kekuatan kultural maupun sosial.

Berdasarkan latar belakang tersebut untuk membahas lebih dalam tumbuh dan berkembangnya batik Pekalongan menggunakan teori akulturasi atau culture contect yang dikemukakan oleh Koentjaraningrat (2009:202) bahwa pertama, suatu kebudayaan tertentu yang dihadapkan dengan unsur-unsur dari suatu kebudayaan asing dengan sedemikian rupa, sehingga unsur-unsur kebudayaan asing itu lambat laun diterima dan diolah ke dalam kebudayaan sendiri tanpa menyebabkan hilangnya kepribadian budaya itu sendiri. Kedua adalah teori yang dikemukaan oleh David Kaplan dan Robert A. Manners mengenai teori adaptasi sebagai proses hubungan sistem budaya dengan lingkungannya. Lingkungan dapat membuahkan dampak yang berbeda-beda ragamnya.

\section{Sejarah Batik}

Secara etimologis istilah batik berasal dari kata yang berakhiran "tik", berasal dari kata menitik yang berarti menetes. Dalam bahasa Jawa krama batik disebut seratan, dalam bahasa Jawa ngoko disebut tulis, yang dimaksud dengan menulis dengan lilin. Menurut terminologinya, batik adalah gambar/ motif yang dihasilkan dengan menggunakan alat canting atau sejenisnya dengan bahan lilin sebagai penahan masuknya warna. Jadi, batik adalah 
gambaran atau hiasan pada kain atau bahan dasar lain yang dihasilkan melalui proses tutup celup dengan lilin yang kemudian diproses dengan cara tertentu (A. N. Suyanto, 2002: 2). Banyak litelatur tentang batik, namun berdasarkan literatur yang ada, sulit mengetahui kapan persisnya batik mulai berkembang di Indonesia. Sekalipun sejumlah sumber yakin bahwa corak batik klasik yang ada di Indonesia memiliki kemiripan dengan hiasan pahatan yang terdapat di bangunan-bangunan kuno, misalnya pahatan batu di candi yang dibangun pada masa Hindu. Lewat asumsi ini, diperkirakan batik telah berkembang sebelum masehi pada masa kerajaan Hindu di Nusantara.

Teknik membatik telah dikenal sejak ribuan tahun yang silam. Tidak ada keterangan sejarah yang cukup jelas tentang asal usul batik. Ada yang menduga teknik berasal dari bangsa Sumeria, kemudian dikembangkan di Jawa setelah dibawa oleh para pedagang India. Saat ini batik bisa ditemukan di banyak negara seperti Indonesia, Malaysia, Thailand, India, Sri Lanka, dan Iran Selain di Asia, batik juga sangat populer dibeberapa negara dibenua Afrika. Walaupun demikian, batik yang sangat terkenal di dunia adalah batik yang berasal dari Indonesia terutama dari Jawa.

Tradisi membatik pada mulanya merupakan tradisi yang turun temurun, sehingga suatu motif dapat dikenali berasal dari batik keluarga tertentu. Beberapa motif batik dapat menunjukkan status seseorang. Bahkan sampai saat ini, beberapa motif batik tradisional hanya dipakai oleh keluarga kraton Yogyakarta dan Surakarta. Batik merupakan warisan nenek moyang Indonesia (Jawa) yang sampai saat ini masih ada.
Sebelum benang katun dikenal, raja-raja zaman dulu senang dengan lukisan-lukisan. Lukisan itu ditempatkan pada daun lontar. Hal itu terjadi sekitar abad ke-13 yang kemudian ada kaitannya dengan corak-corak batik di atas kain tenun. Corak-corak batik mirip dengan relif-relif gambar candi dari batu yang diukir atau ukiran kayu.

Batik dulunya hanya dikerjakan terbatas didalam Kraton, hasilnya untuk pakaian raja dan keluarga serta orangorang lingkungan terdekatnya. Banyaknya orang-orang dekat raja yang tinggal diluar kraton, maka batik dibawa oleh mereka keluar kraton dan dikerjakan di tempatnya masing-masing. Lama kelamaan batik ditiru oleh rakyat terdekat dan selanjutnya meluas menjadi pekerjaan kaum wanita dalam rumah tangga untuk mengisi waktu senggang. Kemudian batik yang tadinya hanya pakaian keluarga kraton, makin digemari masyarakat, baik wanita maupun pria, bahkan batik menjadi satu hasil produk industri. Sejarah perbatikan di Pulau Jawa lebih dominan dibanding daerah lain. Faktor penyebabnya, sejak zaman dulu Pulau Jawa memiliki kepadatan penduduk paling tinggi dibanding wilayah lain. Dengan tingkat kepadatan penduduk yang tinggi, Pulau Jawa menjadi pusat berbagai kegiatan ekonomi dan perdagangan serta pusat penyebaran agama dan budaya.Sesuai dengan kondisi sosial kemasyarakatan pada masa itu, apa yang menjadi aspirasi kerajaan menjadi indentik dengan perkembangan masyarakatnya.

Pembatikan didaerah Jawa menyebar luas semenjak Kerajaan Mataram ke-I dengan rajanya Panembahan Senopati. Setelah kerajaan Mataram terpecah menjadi Yogyakarta dan 
Surakarta sekitar abad 17, 18 dan 19, batik terus berkembang luas, khususnya diwilayah pulau Jawa.Akibat peperangan antara keluarga raja-raja maupun antara kerajaan dengan penjajah Belanda, banyak keluarga raja yang mengungsi dan menetap didaerah-daerah baru, antara lain hijrah ke Banyumas, Pekalongan, dan kedaerah Timur Ponorogo, Tulungagung dan sebagainya. Dalam pengungsian itu mereka kemudian mengembangkan pembatikan di pelosok Pulau Jawa dan corak batik pun berkembang menurut alam dan daerah baru itu (www.ppip.or.id).

\section{Pekalongan Kuno}

Kali loji adalah sebuah sungai yang megalir membelah kota Pekalongan. Orang menyebutnya Sungai Loji karena sungai itu melewati Loji yaitu sebuah gedung penjara yang dibangun oleh Pemerintah Kolonial Belanda. Sungai merupakan urat nadi bagi penduduk Pekalongan sejak zaman dahulu ketika Pekalongan mengalami masa kuno yaitu masa Hindu Jawa kemudian ke masa Islam hingga masa kolonial. Pada masa kolonial, Sungai Loji masih digunakan sebagai sarana lalu lintas yang menghubungkan daerah pedalaman dan daerah pesisir.Sungai Loji yang mengalir dari pertemuan anak Sungai Retno Sumilir dengan Sungai Kupang di hulu kaki pegunungan Rogojembangan disebut juga Sungai Kupang atau Sungai Masin karena sungai itu melewati Desa Masin. Desa itu disebut-sebut dalam sejarah Hindu Klasik oleh Purbatjaraka dalam menentukan Kerajaan Mo-Ho-Sin atau Hasin. Kerajaan tersebut merupakan kerajaan Hindu di Jawa yang berkembang pada permulaan abad X Masehi. Pertumbuhan penduduk dan permukiman yang terjadi pada kota Pekalongan tidak telepas dari peranan sungai sebagai sarana lalu lintas. Dalam sejarah kota-kota di Jawa, pola semacam itu merupakan perkembangan lebih lanjut dari permukiman sebelumnya, seperti halnya Sungai Premulung di desa Laweyan Solo. Perkembangan pemukiman pada masa Pekalongan Kuno diawali dari daerah hulu sungai Loji karena sungai tersebut telah menghubungkan sejarah dari masa Pekalongan Kuno (masa Hindu Klasik) sampai dengan Pekalongan sekarang ini yang dimulai pada masa Islam.

Sebelum pantai purba mengalami sedimentasi sehingga membentuk kota pantai seperti Pekalongan sekarang ini, desa-desa kuno yang disebut wanua, sima, thani atau swatantra berada di daerah pegunungan. Desa yang disebut wanua dan desa tingkat swatantra (sima) seperti Wonopringgo, Kajen, Wonotunggal, Petungkriyono, Talun dan Telaga Pakis, merupakan desa-desa kuno dan pada umumnya tidak jauh dari hulu sungai Kupang. Desa-desa tersebut merupakan wilayah merdeka selama tiga abad setelah kekuasaan Wangsa Sanjaya berakhir dan digantikan oleh Wangsa Syailendra. Desadesa itu tidak dijadikan sasaran pengembangan wilayah oleh raja-raja Mataram Hindu-Jawa Tengah berikutnya. Pusat kekuasaan lebih diarahkan ke daerah pedalaman Jawa Tengan dan Jawa Timur. Namun demikian, adanya pelabuhan kuno di Doro menjadikan daerah ini menciptakan peradaban baru setelah masa pra sejarah yang berlangsung selama puluhan abad. Ada dua buah desa (wanua) yang telah menjadi sima (daerah swatantra) di Desa Linggo Asri, Telaga Pakis, dan Petungkriyono. Mereka memiliki bangunan suci sebagai tempat peribadatan umat Hindu. Kedua desa tersebut sebagai pusat agama karena ditemukan bukti-bukti peninggalan berupa bangunan pura dan 
batu pemujaan seperti lingga dan menhir. Pada masa itu, kehidupan sosial dan ekonomi masyarakat Pekalongan Kuno berkembangan sangat baik temasuk juga kehidupan keagamaan. Pada umumnya, letak desa-desa tersebut tidak terlalu jauh dengan kawasan percandian Dataran Tinggi Dieng (Indihiyang). Candi-candi tempat pemujaan maupun candi makam di Dieng dianggap sebagai tempat suci para dewa oleh masyarakat Hindu Jawa Kuno dan dihormati oleh kerabat Wangsa Sanjaya.

Sistem kemasyarakatan yang berlaku pada masa Pekalongan Kuno adalah mengikuti struktur kemasyarakatan Jawa pada masa Mataram Hindu. Sebagaian besar perekonomian penduduk tertumpu pada sektor pertanian, sedangkan perdagangan dan kerajinan dikuasai oleh orang asing yaitu Cina dan Keling. Pencetakan sawah untuk menanam padi mengikuti kontur tanah yang cenderung mengarah ke utara. Dalam membangun sistem pengairan dan pertanian dapat diketahui dengan adanya peninggalan kuno berupa jala dwara (saluran air) di Desa Kaso dan Patung Ganesha yang ditemukan di sawah-sawah pada setiap desa, seperti di Doro, Jolotigo atau Wonotunggal. Patung Ganesha tersebut dianggap oleh masyarakat Hindu sebagai penjelmaan Dewa Syiwa dalam bentuknya sebagai dewa ilmu dan penjaga kelestarian. Sebagaimana halnya namanama desa di Jawa Kuno yang pada umumnya sangat berkaitan erat dengan status tanah dan keadaan alam, Linggo Asri dan Telaga Pakis adalah sebuah sima yang di dalamnya terdapat bangunan suci dengan batu lingga dan yoni. Pada mulanya Wonopringgo adalah sebuah wanua (desa) sedangkan Kajen berarti daerah yang dihormati atau milik penguasa/raja (Driwya
Haji) dan sebagai daerah yang berstatus sima, maka daerah itu merupakan pencetakan sawah sampai ke utara. Menurut aturan yang berlaku pada masa pemerintahan Jawa Kuno, daerah yang berstatus sima tidak dikenai pajak. Belum ada sumber prasasti di Pekalongan yang menerangkan bahwa Desa Kajen menjadi daerah swatantra pada masa Pekalongan Kuno yang statusnya ada dalam kekuasaan raja lain dan Desa Kajen berdiri sendiri dan daerah tersebut diperintah oleh pejabat atau penguasa setempat. $\mathrm{Hal}$ ini dikarenakan sejak surutnya kekuasaan Sanjaya maupun Syailendra di daerah Jawa, daerah itu lepas dari pengwasan penguasa Hindu-Jawa selama lebih dari tiga abad. Sampai dengan masa colonial, status Kajen masih disebut sebagai tanah lungguh. Pada masa kuno, status lungguh sama dengan watak, yaitu sebuah desa yang mempunyai wilayah tertentu atau menguasai desa lainya selain sebagai sebuah sima, Kajen juga merupakan bandar yang bernama Bandar Guminsang.

\section{Batik Pekalongan Pada Awalnya}

Pekalongan sebagai daerah penghasil batik terbagi atas daerah kota Pekalongan dan wilayah daerah Kabupaten. Sebagian wilayah yang menempati dataran tinggi seperti Petungkriyono, Kajen, Lebakbarang, Penigaran, Kandang Serang dan Kesesi adalah wilayah kecamatan yang sejak masa Hindu Klasik merupakan merupakan desa semasa Pekalongan Kuno yang memiliki potensi sebagai penghasil komoditas pertanian dan perkebunan sedangkan wilayah kota kecamatan yang berada di dataran rendah seperti Kedungwuni, Wonopringgo, Pekajangan, 
Tirto dan Pekalongan Kota merupakan daerah penghasil batik.

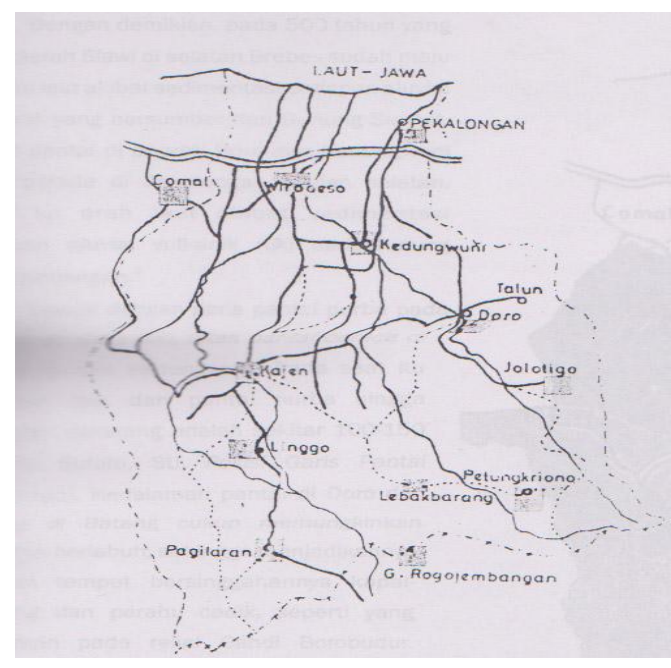

Gambar 1. Kabupaten Pekalongan Kuno (Kusni Asa 2006: 22)

Secara umum, perkembangan ragam hias batik kuno pertama kali diperoleh dari ragam hias pahatan tiga dimensi yang terdapat pada relief candi maupun hiasan arca. Kedua adalah bentuk tumbuhan dan binatang seperti sulur-sulur, daun, bunga, ikan, burung, dan singa. Ketiga adalah bentuk garis atau bidang berbentuk geometris yang mengandung lambang pada perhitungan hari dan bulan serta bentuk bangunan tertutup berupa garis-garis segitiga, setengah bulatan atau bentuk lambang lain. Ragam hias seperti meander, pilin, swastika merupakan ragam hias yang ada pada masa prasejarah, khususnya pada jaman perunggu.

Dalam perkembangan selanjutnya pada masa Hindu abad ke XII batik dan kesakralannya dijadikan sebagai simbol status suatu jabatan. Pada masa itu batik hanya digunakan oleh para Brahmana dan Pendeta, sedangkan para Raja dan keluarganya lebih banyak menerima hadiah kain bercorak atau sulaman dengan hiasan tertentu seperti halnya kain patola dari India. Oleh karena itu kain tersebut semakin langka sehingga sulit dimiliki oleh masyarakat pada umumnya. Adapun ragam hias pada masa Hindu adalah pola kawung, ceplokan, padmasabha dan sebagainya. Pola semacam itu bersumber pada pola lingkaran candi sedangkan pola kawung, tumpal, ceplokan dipengaruhi oleh bentuk ragam hias yang terdapat pada hiasan kuburan batu pada masa prasejarah.

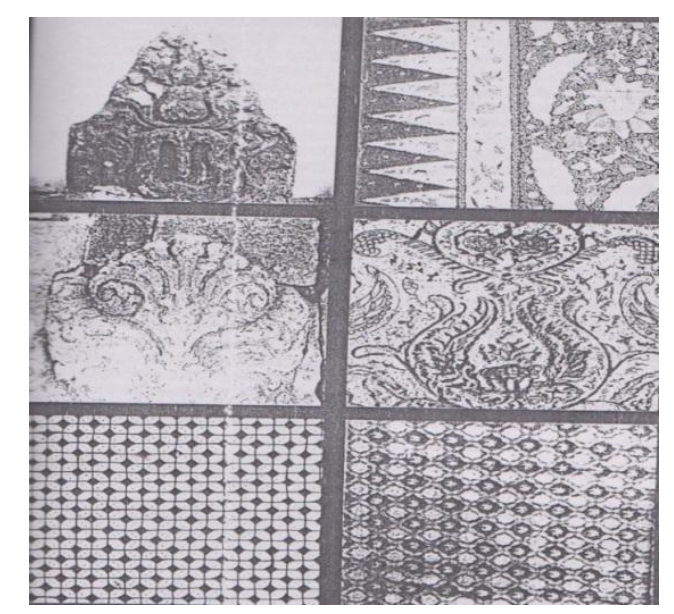

Gambar 2. Batik Ukel, ceplokan, tumpal, kawung , parang dengan isen lung rambat dan sulur daun erupakan motif kuno pada masa klasik Hindu Jawa (Kusni Asa, 2006: 37)

Pada periode ini konsep Ketuhanan sudah lebih sempurna dalam penempatan posisi Tuhan, dunia atas memiliki daya goib sebagai penguasa alam. Pembagian daya magis dari nama-nama penguasa kosmis yang diwakili oleh dewa-dewi tingkat di atasnya yang disebut Sang Hyang Tunggal. Dalam agama Hindu dunia kosmis lebih terorganisasi dengan medium ekspresi berupa candi, patung, lingga, yoni dan hiasan alam yang dibuat dengan indah. Namun benda yang mendatangkan daya gaib tetap tidak berubah yaitu sebagai jembatan antara dunia atas dengan dunia bawah. 
Kedudukan batik sebagai benda sakral pola lama seperti kawung, parang, gurda, grising tetap menjadi pilihan sebagai batik yang mendapat legitimasi sebagai barang indah. Dalam hal ini batik sebagai benda pakai yang memiliki kesakralan. Pada masa pemerintahan Sultan Hamengku Buwono VIII dibuat Undangundang yang mengatur pemakaian polapola batik mulai keluarga Raja hingga pegawai keraton yang rendah. Batik tidak semata-mata berfungsi sebagai busana tetapi juga menunjukan identitas atau derajat si pemakai. Batik pada saat ini banyak dipengaruhi oleh motif pada kain patola. Karena mahalnya kain ini maka masyarakat membuat batik dengan corok yang sama dengan kain patola ini. Batik dengan motif ini kemudian disebut sebagai kain dengan motif jlamprang. Batik tersebut merupakan batik asli Pekalongan dengan makna lambang-lambang agama Hindu Yang beraliran Tantra. Pada awalnya batik jlamprang ini sebagai batik sakral untuk upacara persembahan Den Ayu Lanjar. Kemudian batik jlamprang yang memiliki warna-warna yang cerah itu berkembang sampai ke daerah pedalaman, bahkan mampu menembus tembok keraton. Ragam hias batik jlamprang yang berkembang di pedalaman ditampilkan sesuai dengan warna batik keraton yaitu biru, coklat, soga, dan putih.

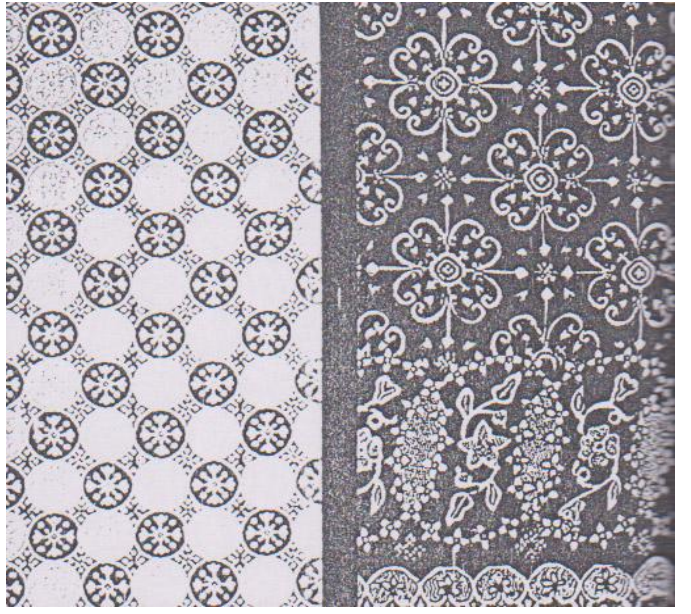

Gambar 3. Batik Jlamprang untuk upacara

Persembahan Den Ayu Lanjar Kusni Asa 2006:65

Kemudian muncul batik dengan motif Merak ngigel, simbol burung merak menari yang terlukis pada batik telah memberikan makna tentang sifat masyarakat yang tidak ingin tertindas tetapi indipenden dan mandiri. Apabila ada tekanan dari luar, mereka tidak segera melawan dengan kekerasan melainkan dengan pengorbanan harta karena mereka berpendapat bahwa hal itu adalah jalan terbaik daripada mengadakan pemberontakan. Dalam hal ini masyarakat Pekalongan lebih banyak mengekspresikan sesuatu dengan dilukis.

Kusni Asa dalam bukunya juga menjelaskan bahwa pada masa Pekalongan Baru sejak abad XIV ketika penduduk Cina yang mengiringi Cheng-Ho singgah di Pekalongan dan bermukim di kampung Sampangan yang terletak di dekat sungai Loji. Kampung Sampanan juga disebut kampung Pecinan karena sejak awal terjadinya pemukiman telah menjadi tempat hunian masyarakat Cina. Penduduk Tionghoa menempati wilayah di sepanjang tepi sungai dan kampungnya disebut pecinan. Kelompok pedagang Arab yang menyatu dengan masyarakat muslim, basis usahanya adalah bahan sandang dan hasil bumi, karena hasil bumi berada di wilayah 
pedesaan (pedalaman), maka mobilisasi ekonomi antara desa dan kota dikuasai oleh para pedagang Arab dan muslim. Mereka keluar masuk desa sambil menyebarkan agama Islam. Pada umumnya perkembangan batik pada periode awal Pekalongan baru mengikuti perkembangan penduduk muslim yang terjadi di kota-kota pesisir utara Jawa yang menggunakan kain sarung untuk mengganti bebed atau tapih. Kain sarung berupa kain batik digunakan pula sebagai saran untuk alat ibadah selain sebagai busana. Sementara itu penduduk Tionghoa dengan membuat kain panjang yang dijadikan tapih. Kedua kelompok etnis tersebut memiliki tradisi dalam mengembangkan kreasi batiknya.

Sebelum kedatangan bangsa pedagang dari Arab, India, Eropa dan Cina masyarakat Pekalongan telah mengenal batik. Batik pada saat itu digunakan sebagai keperluan sendiri oleh masyarakat "kampung"dan untuk masyarakat juragan pribumi sebagai keperluan perdagangan. Batik dibuat masih mengaju pada ragam hias yang berasal dari alam sekitar dan mengacu pada sumber pola batik keraton.

\section{Pengaruh India}

Kain Patola , sembagi dari Gujarat dan pantai Coramandel India sangat digemari masyarakat bangsawan dan orang kaya di Nusantara. Sejak kerajaan Sriwijaya pada abad 7 dan disusul kerajaan majapahit hinggga abad ke 16-17, kain ini sangat mempengaruhi motif dan corak batik Pekalongan. Di Pekalongan dengan terinspirasi dengan motif kain Patola kemudian lahir batik Jlamprang. Jenis batik ini banyak dibuat oleh masyarakat keturunan Arab, desa Krapyak. Motif Jlamprang ini dibuat dengan warna yang lebih bervariatif.

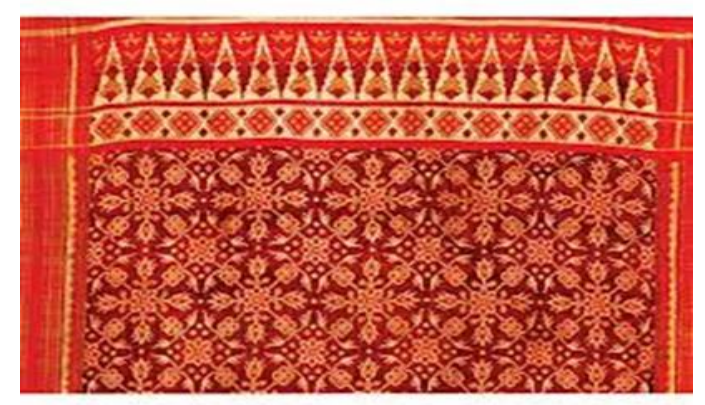

Gambar 4. Motif Kain Patola India

Koleksi : H. Santoso Doellah,2002

\section{Pengaruh Eropa}

Runtuhnya VOC dan kemudian digantikan oleh pemerintah Kerajaan Belanda menyebabkan makin banyaknya orang Belanda yang bermigrasi ke Indonesia. Pertambahan jumlah pemukiman Eropameningkatkan permintaan kain batik, karean ternyata sarung dan kebaya sangat sesuai dengan tata busana wanita Belanda di daerah tropis. Pada awalnya batik Belanda menampilkan ragam hias mirip lereng dan lung-lungan, serta bertema dongeng populer seperti Little red riding, Putih Salju dengan tujuh kurcaci. Seiring dengan pengaruh jaman yang menghendaki polapola yang memampilan jati diri secara jelas, pola semacam itu tidak tampak lagi dan digantikan dengan pola yang benarbenar bernuansa Belanda yaitu rangkaian bunga, buket besar ataupun burung bangau di tengah rumpun tanaman air.

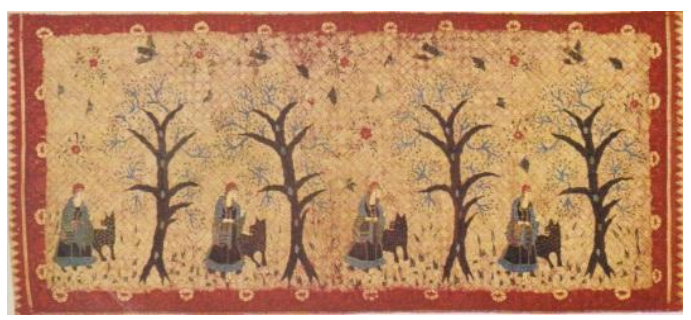

Gambar 5. Batik Pola Little Red Riding Hood Koleksi : Santoso Doellah,2002 


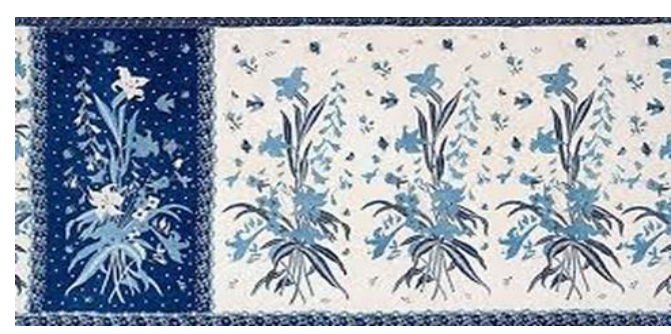

Gambar 6. Batik Pola Buket

Koleksi : Santoso Doellah,2002

\section{Pengaruh Cina}

Meskipun orang Cina datang ke Indonesia lebih dahulu daripada orang Belanda namun batik Cina baru muncul setelah batik Belanda. Batik ini diproduksi oleh sebagian masyarakat Cina dengan pengaruh dan tata warna dan budaya leluhurnya. Batik Cina lebih kurang sampai pada tahun 1910 terbatas hanya untuk keperluan upacara keagamaan dan sarung batik dengan pola budaya Cina. Kemudian setelah tahun 1910 banyak dianggap sebagai adikarya di samping batik Belanda. Ketika batik cina mulai membanjiri pasar dan kebutuhan batik meningkat, hal ini tidak disiakan pedagang Cina dengan memanfaatkan peluang tersebut dengan membuat batik dengan pola dan ragam hias yang mengandung unsur budaya Eropa, meskipun dengan tata warna yang berbeda. Warna yang munculpun sesuai dengan warna masyarakat Cina, seperti merah, biru lembayung, hijau, merah muda dan biru muda.

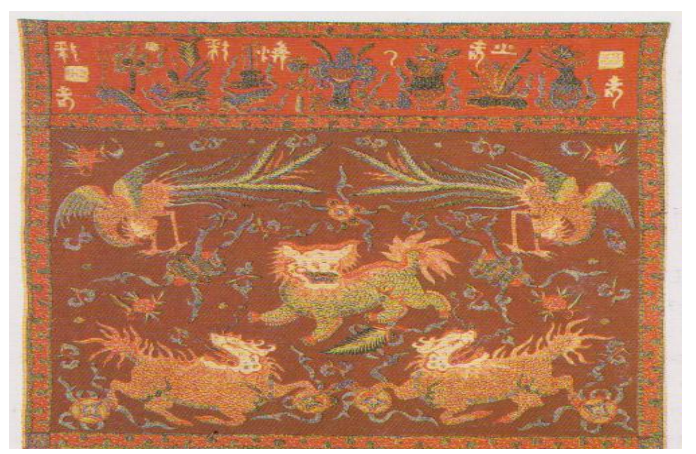

Gambar 7. Tok Wi Cina

Koleksi : Santoso Doelah,2002

\section{Pengaruh Jepang}

Dimasa penjajahan Jepang para pengusaha ditekan untuk memenuhi kepentingan militer Jepang agar mereka bersedia membuat batik pilihan Jepang, yang terutama untuk hadiah. Beberapa batik dibuat dibawah perintah dan pengawasn ketat pemerintah Jepang dengan pola baru yang mirip dengan kainkain tradisional Jepang. Batik pada masa ini yang kemudian dikenal dengan batik Jawa Hokokai. Batik yang lahir pada jaman ini pola dan warna sangat dipengaruhi budaya Jepang, walaupun latar masih menampakan pola ornamen batik asli Jawa. Ragam hias bunga sakura, krisan, dahlia dan angrek dengan bentuk pangkaan atau lung-lungan dan tanbahan kupu ditata diatas latar pola motif jawa seperti parang, lereng, ceplok. Sosok burung merak juga sesekali muncul karena burung merak di Jepang melambangkan keindahan dan keanggunan. Ragam Rona warna yang kuat, yakni warna kuning, lembayung, merah muda dan merah merupakan warna yang secara jelas menggambarkan nuansa dan cita-rasa Jepang. Salah satu penatan yang sangat jelas menjukan pengaruh Jepang adalah bagian pola pinggiran yang yang terdiri atas ragam hias bunga dan kupu yang diatur dari pojok atas ke arah bawah atau pojok bawah ke arah samping, seperti tata susun pada baju kimono. 


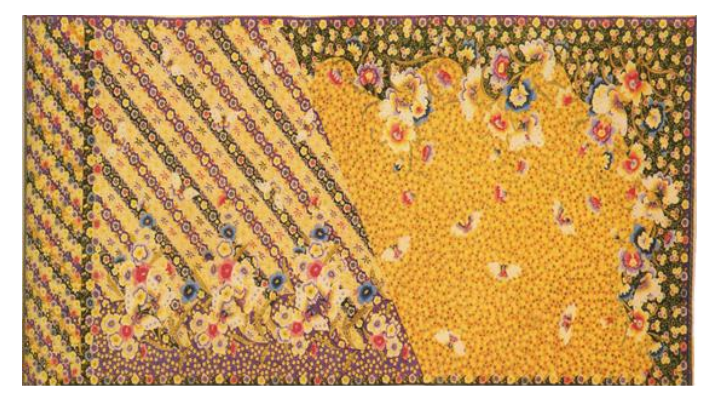

Gambar 8. Motif : Lereng Bunga dan Bunga Sakura Koleksi : H. Santoso Doellah,2002

Dalam memahami peranan batik
yang disertai dengan perubahan sosial
yang terjadi di Pekalongan terlihat adanya
fase-fase pengembangan yang berkesinambungan. Dari fase tersebut diperoleh gambaran sejauh mana pengaruhnya bagi kehidupan masyarakat. Terkait dengan sejarah perkembangan dan pertumbuhan masyarakat pengguna batik yang bersamaan dengan perubahan yang terjadi sebelumnya., ada beberapa segi yang dapat dianalisis, yaitu fungsi batik dalam bidang keagamaan, dan fungsi batik dalam bidang ekonomi. Hal ini terutama berkaitan dengan perubahan ekoliogi masa peralihan Pekalongan kuno yang berpusat dipegunungan yaitu, Kajen, Petung Kriyono. Pada saat itu batik berfungsi batik semata-mata digunakan oleh masyarakat tertentu untuk keperuluan ritual keagamaan.

Pada periode Pekalongan Baru mengikuti perkembangan penduduk muslim yang terjadi di kota pesisir utara Jawa yang menggunakan kain sarung untuk menganti tapih.kain sarung tersebut juga digunakan sebagai saran beribadah selain sebagai busana. Sementara Tionghoa peranakan meneruskan tradisi orang tua mereka dengan membuat kain batik yang dijadikan tapih. Kedua kelompok tersebut memiliki tradisi dalam mengembangkan kreasi batiknya. Pada perkembangan selanjutnya pertemuan dari masyarakt pembatik tersebut melahirkan pola campuran yang akhirnyamenjadi terbesar dari khas pola batik Pekalongan deanga segala ragam dan warnanya. Dengan demikian apabila kita cermati lebih jauh maka timbul dan berkembangnya polapola campuran tesebut mangawali perkambangan pola tradisional meskipun terbatas pada pola yang sudah ada.

\section{Kesimpulan}

Dari pembahasan diatas dapat disimpulkan bahwa karya batik pada saat terpengaruh oleh India, batik cenderung menirukan motif kain tenun patola dari India dengan walaupun teknik pembuatan batik. Kedua pada saat kedatangan pemerintahan Belanda yang mengakibatkan banyaknya imigran ke Indonesia motif kain batik menampilkan ragam hias mirip lereng dan lung-lungan, serta bertema dongeng populer seperti Little red riding, Putih Salju dengan tujuh kurcaci, kemudian pola semacam itu tidak tampak lagi dan digantikan dengan pola yang benar-benar bernuansa Belanda yaitu rangkaian bunga, buket besar ataupun burung bangau di tengah rumpun tanaman air. Begitu juga dengan warnanya sesuai selera masyarakat Belanda. Ketiga dengan adanya pengaruh Cina batik memampilkan unsur kebudayaannya, walaupun demikian tetap terpengaruh juga oleh budaya Belanda, hanya warnya saja yang sedikit berbeda. Keempat saat batik terpengaruh oleh budaya Jepang motif bunga sakura, krisan, dahlia dan angrek dengan bentuk pangkaan atau lung-lungan/ tumbahan dan kupu. Ragam Rona warna yang kuat, yakni warna kuning, lembayung, merah muda dan merah merupakan warna yang secara jelas menggambarkan nuansa dan cita-rasa 
Jepang. Salah satu penatan yang sangat jelas menjukan pengaruh Jepang adalah bagian pola pinggiran yang yang terdiri atas ragam hias bunga dan kupu yang diatur dari pojok atas ke arah bawah atau pojok bawah ke arah samping, seperti tata susun pada baju kimono.

Dalam hal ini jelas batik yang merupakan karya seni budaya bangsa Indonesia yang dikagumi oleh mancanegara. Dalam perkembangannya sebagai suatu karya budaya, karya adiluhung yang tidak bisa terlepas dari pengaruh jaman dan lingkungan. Fakta dalam perjalan sejarah membuktikan telah membuktikan bahwa kedua unsur pengaruh ini memicu dan memacu kehadiran batik yang selaras dengan nada budaya yang mempengaruhinya. Hal ini pun berlaku di semua daerah penghasil batik yang lain.

Sejarah mencatat bahwa para seniman yang terlibat dalam pembuatan batik dalam pengembangan karya seni sangat tanggap dan peka terhadap setiap kehadiran pengaruh luar. Batik selama inipun mampu menyerap setiap pengaruh yang timbul.

\section{DAFTAR PUSTAKA}

Asa, Kusni, Batik Pekalongan Dalam Lintasan Sejarah, Paguyuban Pecinta Batik Pekalongan, 2006

Doellah, Santoso, Batik Pengaruh Jaman Dan Lingkungan, Surakarta : Danar Hadi, 2002

Fay, Brian.,Filsafat IImu Sosial Komtemporer , Yogyakarta : Jendela, 2002
Kardi, Marsan.,dkk, "Sejarah Pembatikan Indonesia", Prosiding Makalah seminar Batik Pekalongan, 2005

Kaplan, David., Teori Budaya, Yogyakarta : Pustaka Pelajar, 2002

Koentjaraningrat, Pengantar IImu Antropologi, Jakarta : Renika Cipta, 2009

Sjafi'l, Achmad, Kekriyaan Nusantara, Surakarta : ISI Pres Surakarta, 2007

Syabana, Alie, Dudung, "Perkembangan Industri Batik Pekalongan Abad 19 Sampai Dengan Sekarang", Prosiding Seminar Batik Pekalongan 18-19 Maret, 2005

http/www.pekalongankab.go.id http/www.ppip.or.id 